\title{
CYTOKINESIS BLOCK MICRONUCLEUS ASSAY IN HUMAN LYMPHOCYTES AFTER EXPOSURE TO Ru(III) THIOSEMICARBAZONE COMPLEXES IN VITRO
}

\author{
N. Ljubijankićr ${ }^{1, *}$, M. Stanković2 ${ }^{2}$ V. Tešević ${ }^{3}$, S. Grgurić-Šipka ${ }^{3}$, M. \\ Jadranin $^{4}$, S. Begić ${ }^{1}$ and E. Šabanović ${ }^{1}$ \\ ${ }^{1}$ University of Sarajevo, Faculty of Science - Department of Chemistry, \\ 71000 Sarajevo, Bosnia and Herzegovina \\ ${ }^{2}$ Nuclear Facilities of Serbia, 11351 Vinča, Serbia \\ ${ }^{3}$ University of Belgrade-Faculty of Chemistry, 11000 Belgrade, Serbia \\ ${ }^{4}$ University of Belgrade-Institute for Chemistry, Technology and Metallurgy, \\ 11000 Belgrade, Serbia \\ *E-mail: nevzetalj@gmail.com
}

\begin{abstract}
This study evaluates the genotoxic potential of two $\mathrm{Ru}(\mathrm{III})$ complexes with thiosemicarbazone based ligands. The complexes were tested for in vitro protective effect on chromosome aberrations in peripheral human lymphocytes using the cytokinesis block micronucleus (CBMN) assay at concentrations $1.5 ; 3.7$ and $7.4 \mu \mathrm{g} / \mathrm{mL}$. The cell culture treated with the tested complexes, at $3.7 \mu \mathrm{g} / \mathrm{mL}$ concentration, decreased a frequency of micronucleus for $37 \%$ and $32 \%$, when compared with the control cell cultures. At concentration of $7.4(1.5) \mu \mathrm{g} / \mathrm{mL}$ of this complexes exhibited slightly lower effect of micronucleus for 30\% (35\%) and 27\% (29\%), when compared with the control cell cultures. Keywords: Ruthenium(III) complexes, Thiosemycarbazone, Chromosome aberrations, Genotoxicity, CBMN assay, Micronucleus
\end{abstract}

(C) RASĀYAN. All rights reserved

\section{INTRODUCTION}

Metal complexes stay a significant resource for creating chemical diversity in the fields of biological, pharmaceutical and medicinal chemistry as antitumor and antimicrobial agents ${ }^{1-3}$. For this purpose, a large number of these complexes are synthesized and intensively investigated ${ }^{4-6}$. In the pre-clinical studies, the biological properties of the potential drug should be thoroughly investigated in order to obtain as much information as possible about its therapeutic and undesirable effects in the living organism ${ }^{7}$. Thiosemicarbazone and their metal complexes are of huge importance as they possess an abundant variety of biological properties including antibacterial, antifungal, antitumor, antiviral, anti malarial activities ${ }^{8-13}$. The chemistry and pharmacological applications of ruthenium thiosemicarbazone complexes have been extensively studied ${ }^{14-19}$. The complexes of $\mathrm{Ru}(\mathrm{III})$ with thiosemicarbazone based ligands exhibited in vitro antitumor activity against MCF-7 tumor cells, significant antiproliferative activities on human lymphocyte culture and inhibitory effects on lung carcinoma A549 cells ${ }^{20,21}$. The synthesis of ruthenium dibasic tridentate thiosemicarbazones complexes with ONS donors are of great significance because of their wide range of medicinal activities ${ }^{22}$.

The analysis of micronuclei (MN) in cultured lymphocytes is increasingly applied as a method to biomonitor human exposure to genotoxic agents, largely because the cytokinesis block (CB) technique, has made it possible to identify cells that have divided once in culture (second cycle interphase cells $\mathrm{s}^{23}$. Micronuclei result from lesions/adducts at the level of DNA or chromosomes, or at the level of proteins directly or indirectly involved in chromosome segregation (e.g. tubulin). Formation of micronuclei originating from chromosome fragments or chromosome loss events requires a mitotic or meiotic 
division. The simplicity of scoring and the wide applicability of the in vitro micronucleus test in different cell types make it an attractive tool to assess cytogenetic abnormality ${ }^{23}$. Micronuclei are efficiently expressed in dividing cells when chromosome breaks are induced by peroxyl radicals. The induced chromosome breaks lag behind at anaphase in dividing cells and are subsequently packaged within nuclear membranes to produce micronucleus. Micronucleus (MN) expression in peripheral blood lymphocytes is well established as a method to monitor chromosome damage in human populations. The analysis of $\mathrm{MN}$ in cultured lymphocytes is increasingly applied as a method to biomonitor human exposure to genotoxic agents largely because the cytokinesis block (CBMN) technique has made it possible to identify cells that have divided once in culture (second cycle interphase cells) ${ }^{24}$.

In our previous paper, we showed synthesis and characterization of the $\mathrm{Ru}(\mathrm{III})$ complexes of the type $\mathrm{Na}\left[\mathrm{RuL}_{2}\right]$ (where $\mathrm{L}=$ dibasic tridentate thiosemicarbazone ligand) ${ }^{14}$. The present article is a continuation of the research activities of the study on in vitro effects of these complexes on human lymphocytes using the CBMN assay.

\section{Synthesis of Ligands and Complexes}

\section{EXPERIMENTAL}

Thiosemicarbazone ligands and complexes were prepared according to the previously published procedures ${ }^{14} .5$-Cl-salicylaldehyde thiosemicarbazone and 5-Br-salicylaldehyde thiosemicarbazone, hereinafter 5-X-SALTSC $(\mathrm{X}=\mathrm{Cl}, \mathrm{Br})$ were prepared in reaction of thiosemicarbazide and 5-Xsalicylaldehyde $(\mathrm{X}=\mathrm{Cl}, \mathrm{Br})$ in the molar ratio $1: 1$ in absolute ethanol. Complexes of $\mathrm{Ru}(\mathrm{III})$ with thiosemicarbazone ligands, hereinafter $\mathrm{Na}\left[\mathrm{Ru}(5-\mathrm{X}-\mathrm{SALTSC}-2 \mathrm{H})_{2}\right]$ (where $\mathrm{X}=\mathrm{Cl}, \mathrm{Br}$ ) were prepared in reaction of appropriate thiosemicarbazone ligand and $\mathrm{RuCl}_{3}$ in the molar ratio $2: 1$ in absolute ethanol.

\section{Subjects}

Venous blood samples were obtained using heparinized sterile vacutainers (Becton Dickinson, Bradford, MA) from five healthy non/smoking female volunteers who had not been exposed to chemicals, drugs or other substances.

A safety protocol concerning blood/born pathogen/biohazard was taken. The volunteers gave their permission for using their blood for the experiment. From each subject, two aliquots of blood, $5 \mathrm{~mL}$ each were obtained. The study complied with the code of ethics of the World Medical Association (Helsinki Declaration of 1964, as revised in 2002) ${ }^{25}$. The blood samples were obtained at the Medical Unit in accordance with current Health and Ethical regulations in Serbia, Law on Health Care $(2005)^{26}$.

\section{Cytokinesis-block MN assay}

The culture lymphocytes were treated with tested complexes $(1.5 ; 3.7$, and $7.4 \mu \mathrm{g} / \mathrm{mL})$. One cell culture served as the control and isolated complexes were not added in this. One cell culture containing Amifostine WR-2721(98\%, S-2[3-aminopropylamino]-ethylphosphothioic acid) at $1.0 \mu \mathrm{g} / \mathrm{mL}$ ), (Marligen-Biosciences,USA), was used as a positive control. They were added to the cultures $25 \mathrm{~h}$ after phytohaemaglutinin (PHA) stimulation and life until harvest. All cultures were incubated in a thermostat at $37^{\circ} \mathrm{C}$. Treatment with the investigated complexes lasted for $19 \mathrm{~h}$, where after all cultures were rinsed with a pure medium, transferred into $5 \mathrm{~mL}$ fresh RPMI 1640 medium (RPMI 1640 Medium + GlutaMAX + 25 mM HEPES; Invitrogen-Gibco-BRL, Vienna, Austria) and incubated for additional $72 \mathrm{~h}$. Approximately 2 x 106 blood lymphocytes were set up in $5 \mathrm{~mL}$ RPMI-1640 medium supplemented with $15 \%$ of calf serum and $2.4 \mu \mathrm{g} / \mathrm{mL}$ of phytohaemaglutinin (Invitrogen-Gibco- BRL). One hour after initiating the cell stimulation, investigated complexes (three concentrations) were added to the samples. The incidence of spontaneously occurring MN in control samples was scored. For MN preparation, the cytokinesis-block method of Fenech and Morley was used with some modifications, as described in Stankovic et al. ${ }^{23,27}$. At least 1000 binucleated (BN) cells per sample were scored, registering MN according to the criteria of Countryman and Heddle, and Fenech and Morley ${ }^{28,23}$. Cytochalasin B (Invitrogen-Gibco-BRL, Vienna, Austria) at a final concentration of $6 \mu \mathrm{g} / \mathrm{mL}$ was added to the samples after $44 \mathrm{~h}$ of culture, and the lymphocyte cultures were incubated for a further $24 \mathrm{~h}$. After $72 \mathrm{~h}$ of culture, the cells were washed with $0.9 \% \mathrm{NaCl}$ (Merck, Sharp and Dohme GMBH., Vienna, Austria), collected by 
centrifugation and treated with a hypotonic solution at $37^{\circ} \mathrm{C}$. The hypotonic solution consisted of $0.56 \%$ $\mathrm{KCl}+0.9 \% \mathrm{NaCl}$ (mixed in equal volumes). The cell suspension was prefixed in methanol/acetic acid (3:1), washed three times with fixative, and dropped onto a clean slide ${ }^{23}$. The slides were air dried and stained with alkaline Giemsa 2\% (Sigma-Aldrich, Vienna, Austria). At least 1000 binucleated (BN) cells per sample were scored, registering MN according to the criteria of Countryman and Heddle and Fenech and Morley ${ }^{28,23}$. The effects of investigated complexes on cell proliferation were estimated by the cytokinesis-block proliferation index (CBPI), calculated as suggested by Surralles and others ${ }^{29}$. CBPI $=$ $[(M \mathrm{I}+2 M \mathrm{II}+3(M \mathrm{III}+M \mathrm{IV})] / \mathrm{N}$, where $M$ I-IV represent the number of cells with 1 to 4 nuclei, respectively, and $M$ is the number of cells scored. For the analysis of $\mathrm{MN}$, only binucleated cells with well-preserved cytoplasm were scored (under a light microscope with a $40 \times 10$ magnification). The criteria for selection of binucleated cells and identification of MN given in the HUMAN project website (http://www.humn.org) were followed ${ }^{25}$. The number of binucleated cells with 1, 2, 3 or more MN was then tabulated. The data for each treatment were expressed as the frequency of MN per 1000 binucleated cells.

\section{Statistics and index calculation}

The statistical analysis was performed using Origin software package version 7.0. The statistical significance of the difference between the data pairs was evaluated by analysis of variance (One way ANOVA) followed by the Tukey test. Statistical difference was considered significant at $\mathrm{p}<0.01$ and $\mathrm{p}<$ 0.05 . The index calculating is presented as the $\%$ of change comparing different groups.

\section{RESULTS AND DISCUSSION}

The structures of tested Ru(III) thiosemicarbazone complexes are shown in Fig.-1.

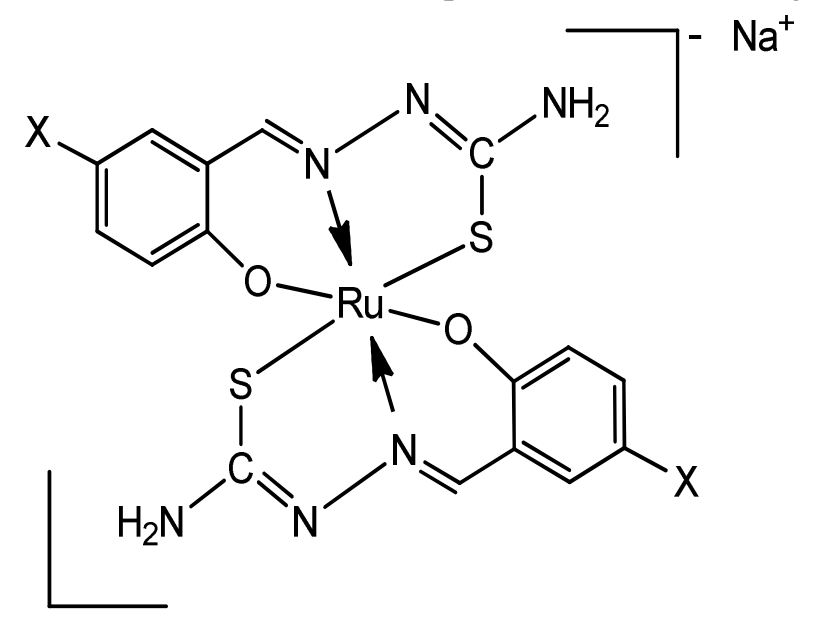

Fig.-1: The structure of $\mathrm{Na}\left[\mathrm{Ru}(5-\mathrm{X}-\mathrm{SALTSC}-2 \mathrm{H})_{2}\right]($ where $\mathrm{X}=\mathrm{Cl}, \mathrm{Br})$

\section{The results of Cytokinesis -Block Micronucleus (CBMN)}

This article summarized the results of using CBMN assay to evaluate the antioxidant potential of complexes in human lymphocytes. They were associated with DNA repair system inhibitor, aminofostine WR-2721. The complexes were tested for in vitro protective effect on chromosome aberrations in peripheral human lymphocytes using CBMN assay at concentrations of $1.5 ; 3.7$ and $7.4 \mu \mathrm{g} / \mathrm{mL}$. The frequencies and distribution of $\mathrm{MN}$ in human lymphocytes were scored. The results are presented in Table-1.

The cell culture treated with the tested complex $\mathrm{Na}\left[\mathrm{Ru}(5-\mathrm{Br}-\mathrm{SALTSC}-2 \mathrm{H})_{2}\right]$ at a concentration of 3.7 $\mu \mathrm{g} / \mathrm{mL}$, exhibit the decreasing the significant $(p<0.01)$, frequency of MN by $37 \%$, when compared with the control cell cultures. Concentration of 1.5 and $7.4 \mu \mathrm{g} / \mathrm{mL}$ of this complex exhibited slightly lower 
effect $(35 \%$ and $30 \%$; $\mathrm{p}<0.01$ and $\mathrm{p}<0.05)$. The complex $\mathrm{Na}\left[\mathrm{Ru}(5-\mathrm{Cl}-\mathrm{SALTSC}-2 \mathrm{H})_{2}\right]$ at a concentration of $3.7 \mu \mathrm{g} / \mathrm{mL}$ also caused significant $(p<0.05)$, decrease of the MN frequency (32\%), but less than former doses, when compared with the control cell cultures. The concentration of 1.5 and $7.4 \mu \mathrm{g} / \mathrm{mL}$ of this complex exhibited decreasing the significant $(\mathrm{p}<0.05)$ frequency of $\mathrm{MN}$ by $(29 \%$ and $27 \%)$ when compared with the control cell cultures.

Table-1: Incidence of MN, cytokinesis-block proliferation index, distribution MN per cells and frequency of MN, measurement in cell cultures of human lymphocytes treated with different concentration of complexes

\begin{tabular}{|c|c|c|c|c|c|}
\hline $\begin{array}{l}\text { Conc. } \\
\mu \mathrm{g} / \mathrm{mL}\end{array}$ & $\begin{array}{c}\mathrm{MN} / 1000 \\
\text { Bn cell }\end{array}$ & $\begin{array}{l}\% \text { Bn cell } \\
\text { with } \mathrm{MN}\end{array}$ & $\begin{array}{c}\text { MN/Bn } \\
\text { Cell }\end{array}$ & CBPI & $\begin{array}{c}\text { Frequency } \\
\text { of MN }\end{array}$ \\
\hline Control & $24.00 \pm 1.82$ & $1.91 \pm 0.17$ & $1.26 \pm 0,05$ & $1.64 \pm 0,03$ & $100,00 \%$ \\
\hline $\begin{array}{c}\text { Amifos. }-1.0 \\
\mu \mathrm{g} / \mathrm{mL}\end{array}$ & $19.69 \pm 0.85$ & $1.56 \pm 0.10$ & $1.27 \pm 0,05$ & $1.97 \pm 0,03$ & $82,04 \%$ \\
\hline $\begin{array}{c}\mathrm{Na}[\mathrm{Ru}(5-\mathrm{Cl}- \\
\left.\mathrm{SALTSC}-2 \mathrm{H})_{2}\right] \\
1.5 \mu \mathrm{g} / \mathrm{mL}\end{array}$ & $17.16 \pm 0.46 a^{*}, b^{*}$ & $1.52 \pm 0.05$ & $1.16 \pm 0,04$ & $1.68 \pm 0,04$ & $71,5 \%$ \\
\hline $\begin{array}{c}\mathrm{Na}[\mathrm{Ru}(5-\mathrm{Cl}- \\
\left.\mathrm{SALTSC}-2 \mathrm{H})_{2}\right] \\
3.7 \mu \mathrm{g} / \mathrm{mL}\end{array}$ & $16.40 \pm 1.60 \mathrm{a}^{*}$ & $1.34 \pm 0.17$ & $1.23 \pm 0,06$ & $1.62 \pm 0,03$ & $68,3 \%$ \\
\hline $\begin{array}{c}\mathrm{Na}[\mathrm{Ru}(5-\mathrm{Cl}- \\
\left.\mathrm{SALTSC}-2 \mathrm{H})_{2}\right] \\
7.4 \mu \mathrm{g} / \mathrm{mL}\end{array}$ & $17.64 \pm 0.52 \mathrm{a}^{*}$ & $1.52 \pm 0.05$ & $1.16 \pm 0,04$ & $1.68 \pm 0,04$ & $73,5 \%$ \\
\hline $\begin{array}{c}\mathrm{Na}[\mathrm{Ru}(5-\mathrm{Br}- \\
\left.\mathrm{SALTSC}-2 \mathrm{H})_{2}\right] \\
1.5 \mu \mathrm{g} / \mathrm{mL}\end{array}$ & $15.59 \pm 1.22 \mathrm{a}, \mathrm{b}^{*}$ & $1.26 \pm 0.11$ & $1.24 \pm 0,05$ & $1.66 \pm 0,05$ & $65,0 \%$ \\
\hline $\begin{array}{c}\mathrm{Na}[\mathrm{Ru}(5-\mathrm{Br}- \\
\left.\mathrm{SALTSC}-2 \mathrm{H})_{2}\right] \\
3.7 \mu \mathrm{g} / \mathrm{mL}\end{array}$ & $15.20 \pm 2.58 \mathrm{a}$ & $1.37 \pm 0.21$ & $1.10 \pm 0,04$ & $1.68 \pm 0,02$ & $63,3 \%$ \\
\hline $\begin{array}{c}\mathrm{Na}[\mathrm{Ru}(5-\mathrm{Br}- \\
\left.\mathrm{SALTSC}-2 \mathrm{H})_{2}\right] \\
7.4 \mu \mathrm{g} / \mathrm{mL}\end{array}$ & $16.75 \pm 1.07 \mathrm{a}^{*}$ & $1.42 \pm 0.12$ & $1.15 \pm 0,07$ & $1.61 \pm 0,02$ & $69,8 \%$ \\
\hline
\end{tabular}

MN/1000 Bn cells - incidence of micronuclei in 1000 binucleated cells

$\%$ Bn cells witch micronuclei

MN/Bn cells - the incidence of micronuclei in binucleated cells.

CBPI- cytokinesis-block proliferation index.

The frequency of $\mathbf{M N} \rightarrow$ incidence of MN presented as \% from control groups in cell cultures of human lymphocytes treated with different concentration of complexes. The statistical significance of the difference between the data pairs was evaluated by analysis of variance (One-way ANOVA) followed by the Tukey test. Statistically, difference was considered significant at $\mathrm{p}<0$.

a Compared with control groups, statistically significant difference $p<0.01$.

$a^{*}$ Compared with control groups, statistically significant difference $\mathrm{p}<0.05$.

b Compared with amifostine - WR 2721, statistically significant difference $\mathrm{p}<0.01$.

b* Compared with amifostine - WR 2721, statistically significant difference $\mathrm{p}<0.05$.

The frequency of $\mathrm{MN}$ is statistically significant $(\mathrm{p}<0.05)$ between cell cultures treated with amifostine $(1$ $\mu \mathrm{g} / \mathrm{mL})$ and cell cultures treated with complexes $\mathrm{Na}\left[\mathrm{Ru}(5-\mathrm{Cl}-\mathrm{SALTSC}-2 \mathrm{H})_{2}\right]$ and $\mathrm{Na}[\mathrm{Ru}(5-\mathrm{Br}-\mathrm{SALTSC}$ $\left.2 \mathrm{H})_{2}\right](1.5 \mu \mathrm{g} / \mathrm{mL})$.

The effect of complexes on cell proliferation was investigated by determining the cytokinesis-block proliferation index (CBPI). Table-1, showed the mean CBPI values and standard errors calculated at different concentrations of complexes. The comparable CBPI values for complexes and aminofostine WR-2721 suggested an inhibitory effect on lymphocyte proliferation of tested complex. Since MN expression is dependent on cell division, quantification of cell proliferation and cell death should be assessed to obtain a sound evaluation of cell kinetics and MN frequencies. 
In this study we found that the lower concentration of complexes possesses beneficial effect on lymphocyte cells culture by decreasing the frequency of MN. Our results provide the evidence of protective effects of tested complexes on cytogenetic and damages in human lymphocytes treated in vitro.

\section{CONCLUSION}

Two ruthenium(III) thiosemicarbazide complexes, $\mathrm{Na}\left[\mathrm{Ru}(5-\mathrm{Cl}-\mathrm{SALTSC}-2 \mathrm{H})_{2}\right]$ and $\mathrm{Na}[\mathrm{Ru}(5-\mathrm{Br}-$ SALTSC-2H $)_{2}$, were tested for antioxidant potential in peripheral human lymphocytes using the CBMN assay. We found that complexes reduced the frequency of $\mathrm{MN}$ in concentration-dependent manner and the medium concentration of $3.7 \mu \mathrm{g} / \mathrm{mL}$ was the most effective. This result is important taking into account that synthetic protectors, used in the treatment of humans, decrease the frequency of MN by around 18\% (Amifostin WR-2721) ${ }^{30}$.

\section{ACKNOWLEDGMENT}

This study is financially supported by the Federal Ministry of Education and Science, Bosnia and Herzegovina, Project No. 05-39-3087-21/16.

\section{REFERENCES}

1. D. Gambino, Curr. Med. Chem., 17, 3616(2010), DOI: 10.2174/092986710793213797

2. S. Arulmurugan, Helen P. Kavitha, and B.R. Venkatraman, Rasayan J. Chem., 3(3), 385(2010)

3. A. Cipurković, E. Horozić, N. Ljubijankić, A. Odobašić, S. Galijašević and M. Saletović, Rasayan J. Chem., 10(4), 1381(2017), DOI: http://dx.doi.org/10.7324/RJC.2017.1041905

4. R. Akkasali, N. Patil and S.D. Angadi, Rasayan J. Chem., 2(1), 81(2009)

5. H.K. Thompson and C. Orvig, Dalton T., 761(2006), DOI: 10.1039/b513476e

6. S. Pattanaik, S.S. Rout, J. Panda, P.K. Sahu and M. Banerjee, Rasayan J. Chem., 4(1), 136(2011)

7. T. Jurca, E. Marian, L.G. Vicaş, M.E. Mureşan and L. Fritea, 2017, Metal Complexes of Pharmaceutical Substances, in: E. Sharmin and F. Zafar (Eds.), Spectroscopic Analyses Developments and Applications, In Tech, pp. 24-125, DOI: 10.5772/65390

8. H. Beraldo and D. Gambino, Mini-Rev. Med. Chem., 4, 31(2004), DOI: 10.2174/1389557043487484

9. C. Marzano, M. Pellei, F. Tisato and C. Santini, Anti-Cancer Agents. Me., 9, 185(2009), DOI: 10.2174/187152009787313837

10. D. Kovala-Demertzi, A. Boccarelli, M.A. Demertzis and M. Coluccia, Chemotherapy, 53(2), 148(2007), DOI: 10.1159/000099986

11. G. Pelosi, The Open Crystallography Journal, 3, 16(2010), DOI: 10.2174/1874846501003010016

12. S.A. Khan, A.M. Asiri, K. Al-Amry and M.A. Malik, Scientific World Journal, Article ID 592375(2014), DOI:10.1155/2014/592375

13. A.A. Al-Amiery, A.A.H. Kadhum and M. Abu Bakar, Bioinorg. Chem. Appl., Article ID 795812(2012), DOI:10.1155/2012/795812

14. N. Ljubijankić, V. Tešević, S. Grgurić-Šipka, M. Jadranin, S. Begić, L. Buljubašić, et al., Bulletin of the Chemists and Technologists of Bosnia and Herzegovina, 47, 1(2016)

15. N.Raja and R.Ramesh, Spectrochimica Acta part A, Molecular and Biomolecular Spectroscopy, 75, 713(2010), DOI: 10.1016/j.saa.2009.11.044

16. P. Subhash, Coordin. Chem. Rev., 63, 127(1985), DOI: 10.1016/0010-8545(85)80022-9

17. T.S. Lobana, R. Sharma, G. Bawa and S. Khanna, Coordin. Chem. Rev., 253, 977(2009), DOI: 10.1016/j.ccr.2008.07.004

18. T.D. Thangadurai and K. Natarajan, Transition Metal Chem., 26, 717(2001), DOI: 10.1023/A:1012081112872

19. F. Basuli, S.M. Peng and S. Bhattacharya, Inorg. Chem.,36, 5645(1997), DOI: 10.1021/ic9705094

20. K. Sampath and C. Jayabalakrishnan, DJ. J. Eng. Chem. Fuel, 1(1), 40(2016), DOI: 10.18831/djchem.org/2016011004

21. R. Prabhakaran, P. Kalaivani, R. Jayakumar, M. Zeller, A.D. Hunter, S.V. Renukadevi, et al., Metallomics, 3, 42(2011), DOI:10.1039/C0MT00062K 
RASĀYAN J. Chem.

Vol. 11 | No. 2 |647- 652 | April - June | 2018

22. R.M. El-Bahnasawy, L.M. Sharaf El-Deen, A.S. El-Table, M.A. Wahba and A. El-Monsef, Eur. Chem. Bull., 3(5), 441(2014), DOI: 10.17628/ecb.2014.3.441-446

23. M. Fenech, Mutat. Res., 285, 35(1993), DOI: 10.1016/0027-5107(93)90049-L

24. M. Fenech, Mutat. Res., 455(1-2), 81(2000), DOI: 10.1016/S0027-5107(00)00065-8

25. M. Fenech, W.P. Chang, M. Kirsch-Volders, N. Holland, S. Bonassi and E. Zeiger, Mutat. Res., 34, 65(2003), DOI:10.1016/S1383-5718(02)00249-8

26. Law on Health Care, Official Gazette of the Republic of Serbia, Parliament of the Republic of Serbia. 107, 112(2005).

27. M. Stanković, V. Tešević, V. Vajs, N. Todorović, S. Milosavljević and D. Gođevac, Planta Med., 74, 730(2007), DOI: 10.1055/s-2008-1074521

28. P.I. Countryman and J.A. Heddle, Mutat. Res., 41, 321(1976), DOI: 10.1016/0027-5107(76)90105-6

29. J. Surralles, N. Xamena, A. Creus, J. Catalan, H. Norppa and R. Marcos, Mutat. Res., 341, 169(1995), DOI: 10.1016/0165-1218(95)90007-1

30. P.I. Kumar and H.C. Goel, Indian J. Exp. Biol., 38, 1003(2000)

[RJC-3004/2018] 